\title{
Are You Really Sitting Comfortably? A Field Study of a Forward Sloping Chair and Sedentary Low Back Pain Sufferers
}

\author{
R. S. BRIDGER AND G. G. JAROS
}

\section{SUMMARY}

A number of authors have suggested that office chairs designed to encourage users to sit with an "open" trunk-thigh angle (approximately 110-120 degrees) will be more comfortable than conventional chairs and will have beneficial consequences for sedentary low back pain sufferers.

This assertion was investigated in a 4 month trial in which $\mathbf{3 5}$ sedentary workers were given a forward sloping chair to use. Ratings of perceived back pain and postural comfort when using the chair were compared with ratings obtained when conventional chairs were used. Additionally, users' comments on both chair types were obtained.

For the sample as a whole, significantly less lower back pain was reported on those occasions when the forward sloping chair was used. However, a number of participants reported no change or more back pain when using the forward sloping chair. Users' comments on the chair highlighted a number of practical advantages and disadvantages which relate to its suitability for use in office settings.

Although the majority of users preferred the forward sloping chair to their usual chairs, the available data do not permit the differential response to the chair to be explained on either personal, occupational, anthropometric or ergonomic grounds. A more clinically orientated investigation would seem to be required.

R. S. Bridger, M.Sc. (Ergonomics)

Head. Ergonomics Group, Dept. of Biomedical Engineering, University of Cape Town Medical School and Groote Schuur Hospital

G. G. Jaros, Pr. Eng., M.SC. (Eng.), Ph.D.

Professor, Head, Dept. of Biomedical Engineering, University of Cape Town Medical School

\section{OPSOMMING}

Verskeie skrywers het aangedui dat kantoorstoele met 'n groot romp-dy hoek (110-120) gemakliker sal wees as die konvensionele kantoorstoele en dat dit ook voordele kan inhou vir lae-rugpyn lyers.

Hierdie stelling is oor ' $n$ tydperk van 4 maande ondersoek. Vyf en dertig (35) kantoor werkers is met stoele met ' $n$ vorentoe helling toegerus. Skattings van rugpyn en gemak is met die skattings vir konvensionele stoele vergelyk. Die gebruikers se kommentaar oor die gebruik van hierdie stoeltipes is ook verkry.

' $n$ Beduidende afname in lae-rugpyn het voorgekom met die gebruik van die stoele met vorentoe hellings. 'n Paar gebruikers het geen veranderings of meer rugpyn ondervind nie. Kommentaar van die gebruikers het ' $n$ paar praktiese voordele en nadele vir die gebruik van hierdie stoele in kantore na vore laat kom.

Alhoewel die meeste deelnemers die stoele met vorentoe hellings bo hul gewone stoele verkies het, is die beskikbare gegewens nie genoeg om die verskil in reaksie op grond van die persoon, beroep, antropometrie of ergonomie te verduidelik nie. ' $n$ Meer kliniese georiënteerde ondersoek blyk nodig te wees.

\section{INTRODUCTION}

In a previous article ${ }^{1}$ some preliminary data were presented concerning the acceptability of a forward sloping chair when used by sedentary workers with a history of lower back pain. The present article summarises data from the completed trial.

The rationale for the use of forwarding sloping chairs has been discussed elsewhere. ${ }^{1}$ However, the assertion that such chairs may have beneficial consequences for sufferers from lower back pain engaged in sedentary occupations, has received little empirical support. Addi- 


\section{AKRON Therapy products from Medical Distributors (Pty) Ltd}

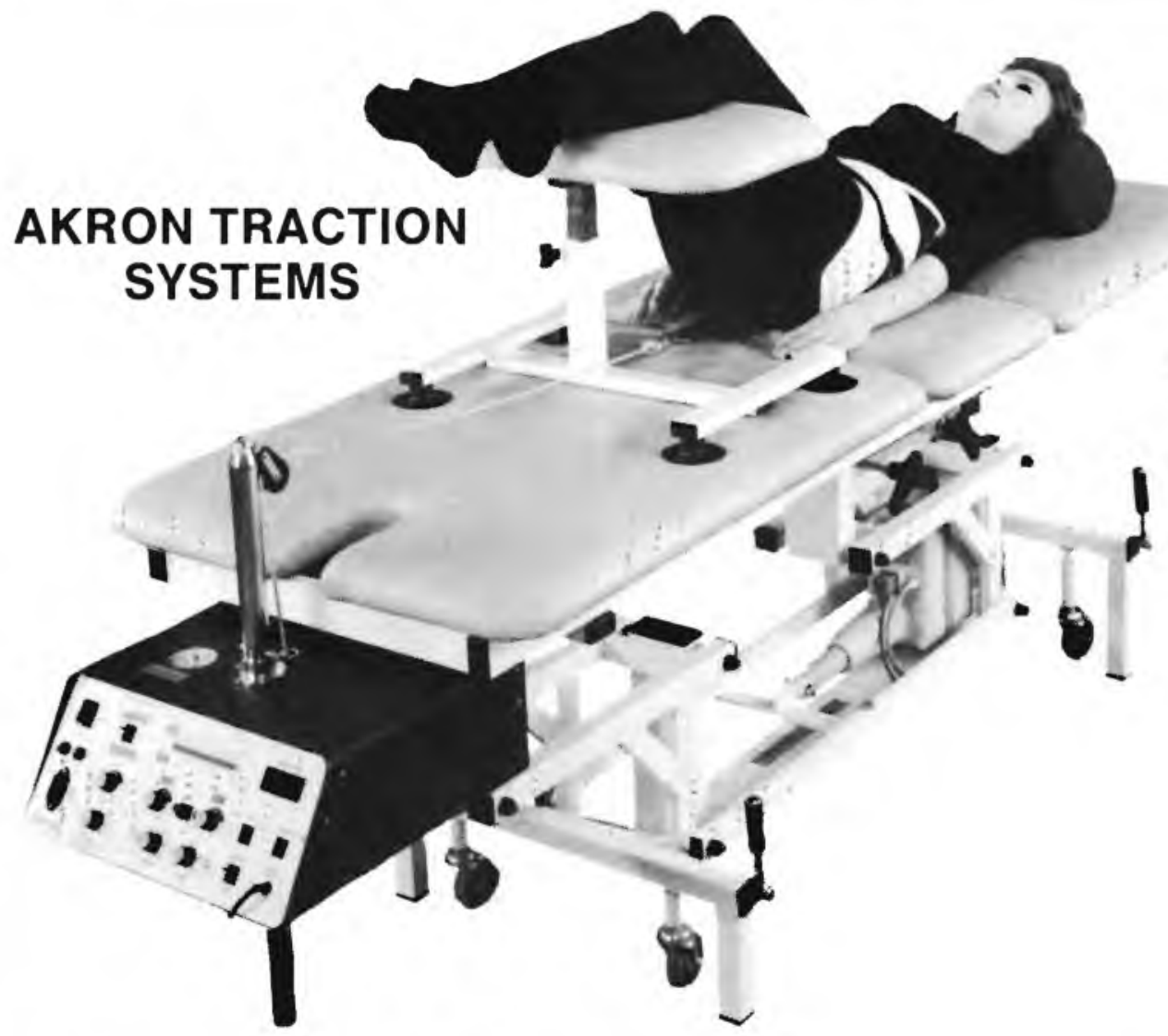

Above illustration shows the new Electric Variable Height Traction Table with progressive-regressive Traction Machine

Close up of The Panel of the progressive-regressive motor.

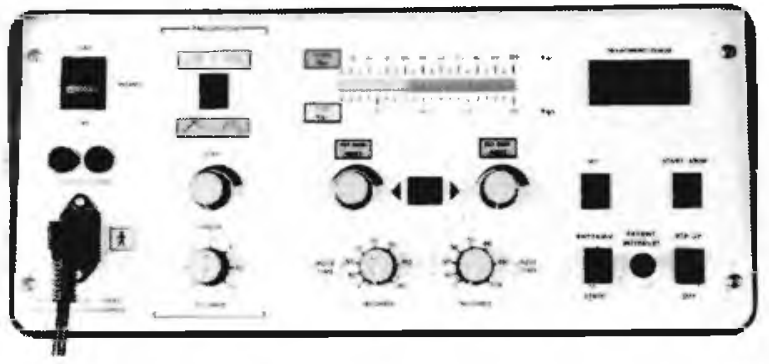

MEDICAL DISTRIBUTORS ${ }_{\text {EOMS BPK }}^{\text {PTYLID }}$

\begin{tabular}{llll}
\hline PO Box 3378 & Johannesburg & 2000 & Phone : 29-0611 \\
\hline PO Box 195 & Cape Town & 8000 & Phone : 47-4440 \\
\hline PO Box 5298 & Durban & 4000 & Phone : $37-1501$ \\
\hline
\end{tabular}




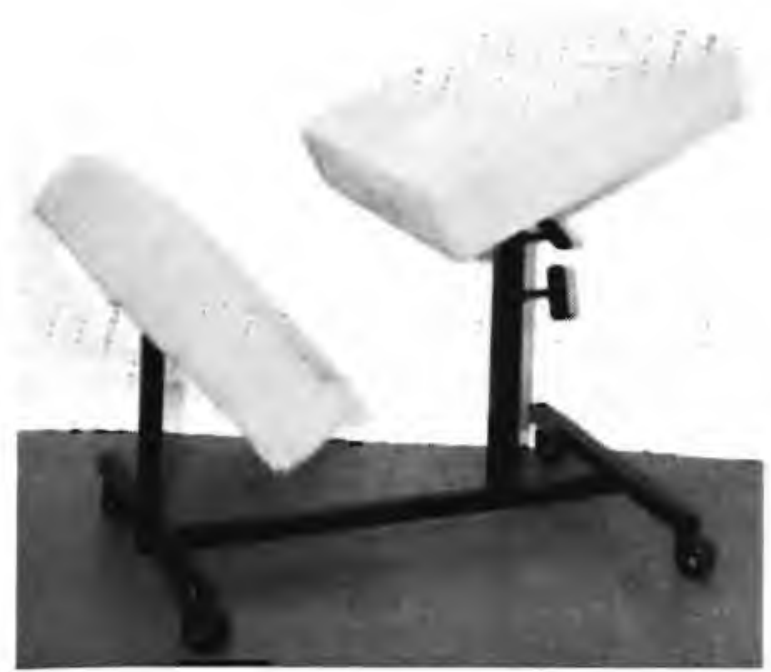

Fig. Forward sloping chair used in the study.

tionally the suitability of such chairs for daily use is not well documented.

The purpose of the present investigation was to test the hypothesis that use of such chairs would lead to reduction in lower back discomfort and to document users' perceptions of the chair in the context of their daily working activities.

\section{METHOD}

The general approach was described by Bridger. Additional points to be noted are as follows:

1. Each participant in the trial sat on the forward sloping chair for two periods of 1 month, interspersed with two monthly periods of sitting on their usual chairs. Interviews were held at each changeover period and at the beginning of the trial - a total of 5 interviews were held with each participant.

2. A total of 35 office workers participated in the evaluation. Table 1 summarises their personal characteristics. The estimated duration of back pain ranged from 3 months to 25 yrs (mean $=9,7$ years). $77 \%$ of the sample had sought treatment from doctors, surgeons or physiotherapists. The number of visits

Table 1. Personal Characteristics of the sample of lower back pain sufferers

$\begin{array}{lrr} & \text { Males } & \text { Females } \\ \text { Age yrs } & 41,9 & \\ \text { mean } & 14,3 & 43,0 \\ \text { s.d. } & 176,6 & 11,2 \\ \text { Stature cms } & 7,3 & 163,0 \\ \text { mean } & & 7,6 \\ \text { s.d. } & 73,9 & \\ \text { Weight kgs } & 10,6 & 58,5 \\ \text { mean } & & 11,0 \\ \text { s.d. } & 7 & 28 \\ \text { Number of } & & \\ \text { subjects } & & \end{array}$

\section{PELVIC TILT CHAIR}

- Three models for different work heights, from office desk to drawing board to bank counter.

- Maintains healthy posture.

- Reduces fatigue in standing occupations, e.g. tellers, draughtsmen.

- Provides comfortable seating position whilst working.

R. J. Projects, P.O. Box 33803, Jeppestown, 2043, Johannesburg. (011) 839-2009 
ranged from 1 to 30 (median $=5$ ). Although detailed diagnostic data were not obtained, there appeared to be three general groups. Group I (5 subjects) had had severe problems treated by surgery. Group 2 (I4 subjects) had similar problems (e.g. lumbar disc degeneration, chronic pain after car accidents) which were treated by non-surgical means. Group 3 (16 subjects) were largely undiagnosed and had sought and received little or no treatment.

\section{Procedure}

The sample was divided into 3 main groups - a managerial group (for example, professor, nursing administrator, medical superintendent), a secretarial/ clerical group (for example, secretary, typist, clerk) and a professional/technical group (for example, cytologist, computer programmer, pathologist).

At the beginning of the investigation, participants were asked to estimate the number of hours they spent sitting in a typical working day. At each subsequent interview, they were asked to make a similar estimate of the amount of time they had spent sitting on the chair in question over the previous month. As well as indicating chair usage, this question was asked in order to obtain data on any changes in work routine which may have systematically influenced back discomfort.

\section{RESULTS}

The mean values of estimated duration of sitting were as follows:

1. Managerial/Administrative workers: $5,6 \mathrm{hrs} /$ day

2. Secretarial/Clerical workers: $6,6 \mathrm{hrs} /$ day

3. Professional/technical workers: $5,2 \mathrm{hrs} /$ day

The difference in estimated sitting duration were statistically significant across groups (Kruskal-Wallis statistic $=7,31 \mathrm{p}<0,05$ ).

Group I participants were relatively unconstrained, engaging in a variety of desk-bound activities (reading, writing, conversation), those in Group 2 were more constrained, spending most of their time doing a limited number of specified tasks (typing, repetitive clerical operations) and those in Group 3 were typically engaged in tasks involving a high degree of postural and visual constraint (for example, using a microscope or visual display unit).

Throughout the evaluation period, the estimates of daily sitting time did not change significantly. The mean estimates (over all groups) were 5,4 and 5,1 hours/day for the first and second months of using the forward sloping chair and 5,0 and 5,2 hours/day for the usual chairs (Friedman chi-square $=2,19, \mathrm{p}>$ $0,05)$.

\section{Low back pain}

Data were obtained from the pain/discomfort ratings placed by participants in the lumbar and sacro-iliac regions of the body diagrams (Table 2). Ratings were recorded, at interview, after each monthly period of sitting, yielding a total of 4 back pain/discomfort data sets, 2 for each type of chair. The ratings were combined over both months and back pain/discomfort was compared according to the chair type used, using the Wilcoxon matched pairs, signed ranks test. A $Z$ value of 4,04 ( $p<0,01,2$-tailed) indicated that the ratings were lower on those occasions when the forward sloping chair was used.

A similar analysis of the ratings of back discomfort outside of working hours yielded a $\mathrm{Z}$ value of 2,10 ( $\mathrm{p}<$ $0,05,2$-tailed), again indicating less pain/discomfort in the months when the forward sloping chair was used.

Reference to Table 2 indicates that ratings were lower in the second month of use in the case of both chairs. An analysis was undertaken to test the significance of this. Non-significant results were obtained for both chair types for backpain during and outside working hours. The rating scale ranged from 1 to 7 (slight discomfort to unbearable pain). All of the mean ratings in Table 2 are very low and the differences between the means are not large in terms of the rating scale. Further analysis revealed that, of the 35 participants, 20 reported a reduction in lower back pain/discomfort in one or both of the months when the forward sloping chair was used. In 8 cases no differences were reported and in the remaining cases, lower back pain/ discomfort was more severe when the forward sloping chair was used. Further analysis was undertaken in

Table 2. Mean levels of back pain/discomfort over the evaluation period

\begin{tabular}{lcccc} 
& \multicolumn{2}{c}{ Forward sloping chair } & \multicolumn{2}{c}{ Usual chair } \\
& First month & Second month & First month & Second month \\
Sitting at work & 0,51 & 0,40 & 1,60 & 1,11 \\
Outside of work & 0,92 & 0,78 & 1,44 & 1,08
\end{tabular}

Table 3. Analysis of participants' ratings of lower back discomfort when sitting (ratings averaged over both monthly sitting periods on each chair). Data were analysed by occupation and then by back history

$\begin{array}{lcccc}\text { Analysis by } & \text { Forward Sloping } & \text { Usual } & \text { Number of } \\ \text { Occupation } & \text { Chair } & \text { Chair } & \text { subjects } & \text { Significance } \\ \text { Group 1 } & 0,6 & 1,6 & 16 & \mathrm{p}<0,025 \\ \text { Group 2 } & 0,3 & 1,2 & 13 & \mathrm{p}<0,01 \\ \text { Group 3 } & 0,3 & 1,8 & 6 & \mathrm{p}<0,025 \\ \text { Analysis by } & & & & \\ \text { back history } & 1,3 & 2,6 & 5 & \mathrm{p}>0,05 \\ \text { Group 1 } & 0,6 & 1,3 & 14 & \mathrm{p}<0,025 \\ \text { Group 2 } & 0,4 & 1,7 & 16 & \mathrm{p}<0,01\end{array}$


order to determine whether these different responses were associated with occupation or back history. Table 3 summarises the results. In all groups, ratings were lower subsequent to the forward sloping chair having been used. In all but one instance, this was statistically significant.

Ratings of lower back pain/discomfort experienced when sitting at work and at other times, were lower in the months when the forward sloping chair was used. However, some of the participants did not experience these reductions. These individuals did not appear to be distributed systematically into any particular occupational or back history group.

Analysis of participants' spontaneous comments revealed that 12 individuals attributed perceived reductions in lower back pain/discomfort directly to use of the forward sloping chair and three of these identified their usual chair as a cause of back pain.

\section{ERGONOMIC ASPECTS OF THE FORWARD SLOPING CHAIR \\ I. Comfort}

29 subjects stated that the forward sloping chair was comfortable. Table 4 shows the general body areas in which participants experienced discomfort when sitting. For the forward sloping chair, discomfort was frequently observed in the lower legs/knees. A past history of knee injury was often mentioned in conjunction with complaints of knee discomfort. For the conventional chairs, the lower back was the site of most of the discomfort. Also 3 subjects had varicose veins in the lower legs and felt this to be a major disadvantage when using the forward sloping chair.

Knee injury and lower limb circulation problems may contra-indicate the general use of this type of chair. More data would appear to be required.

\section{Posture}

The most frequently encountered comment pertaining to the forward sloping chair was that it enabled users to sit with an upright posture. The kneeling posture was commented on favourably by 2 users and 5 users disliked the lower limb constraint which accompanies the use of this type of chair.

Table 4. Pain/discomfort by anatomical region*

$\begin{array}{lcc} & \begin{array}{c}\text { Forward } \\ \text { Sloping } \\ \text { Chair }\end{array} & \begin{array}{c}\text { Usual } \\ \text { Chair }\end{array} \\ \text { Neck/shoulders } & 5 & 11 \\ \text { Upper arms } & 0 & 2 \\ \text { Thoracic spine } & 4 & 6 \\ \text { Lumbar spine/sacro-iliac } & & \\ \text { region } & 19 & 36 \\ \text { Buttocks } & 2 & 0 \\ \text { Thighs } & 3 & 6 \\ \text { Knees } & 11 & 0 \\ \text { Lower legs } & 3 & 2 \\ \text { Feet } & 2 & 5\end{array}$

* Since all participants sat on both chairs twice, there were 70 possible participant recording occasions. Data are the total number of responses for both occasions.

\section{Workspace Design and Anthropometry}

In order to evaluate the arrangement of the existing workplaces, the difference between the anthropometric dimensions of users and the corresponding workplace dimensions were calculated. The following criteria were used:

1. Adequacy of foot/floor contact when sitting on the chair: Popliteal height (with shoes) - seat height (PHS)

2. Adequacy of back support:

Buttock-knee length - seat depth (BKS)

3. Desk work can be carried out when sitting erect without flexing elbows or elevating the shoulders: Sitting elbow height - table height (SET)

4. Minimum visual distance when sitting erect: Sitting eye height - table height (SEH).

Table 5 summarises the results of this analysis. In $74 \%$ of the cases the seat height was found to be greater than the popliteal height (with shoes), suggesting that these users would be able to rest their feet comfortably on the floor only by exerting excess pressure on the posterior aspect of the thigh or by sitting on the edge of the seat and pointing the thighs downwards.

In $30 \%$ of cases, the seat depth was greater than the buttock-knee length making appropriate use of the backrest difficult. In $71 \%$ of cases, sitting elbow height was less than the height of the table.

Reference to typical ergonomics guidelines for furniture design indicated that the conventional furniture was, in general, poorly configured.

Table 5. Analysis of discrepancies between user anthropometry and corresponding workspace dimensions*

$\begin{array}{lcccc} & P H S & B K S & S E T & S E H \\ \text { Mean } & -2,4 & 5,6 & -2,3 & 48,1 \\ \text { S.d. } & 4,7 & 6,6 & 3,9 & 5,4 \\ \text { range } & -13 \text { to }+15 & -7 \text { to }+15 & -11 \text { to }+6 & +36 \text { to }+56\end{array}$

* Data in centimetres

\section{Subjective comments concerning ergonomics and chair design}

No consensus was apparent in the comments about the forward sloping chair. Most of the comments were positive, however. The majority of comments concerning the conventional chairs were negative, the seats being perceived as too high and too deep and the back support inadequate. This is consistent with the results of the analysis in the previous section.

\section{Usability}

This category was introduced to include comments pertaining to the use of the chair in carrying out office tasks. Table 6 summarises the incidence of these spontaneous comments.

A larger number of positive comments were made about the forward sloping chair, the reverse being true for the conventional chairs. For the forward sloping chair, the most frequent comment concerned manoeuvrability. Participants were generally negative or indifferent to their usual chairs. 
Table 6. Comments concerning usability $(n=$ number of participants per item)

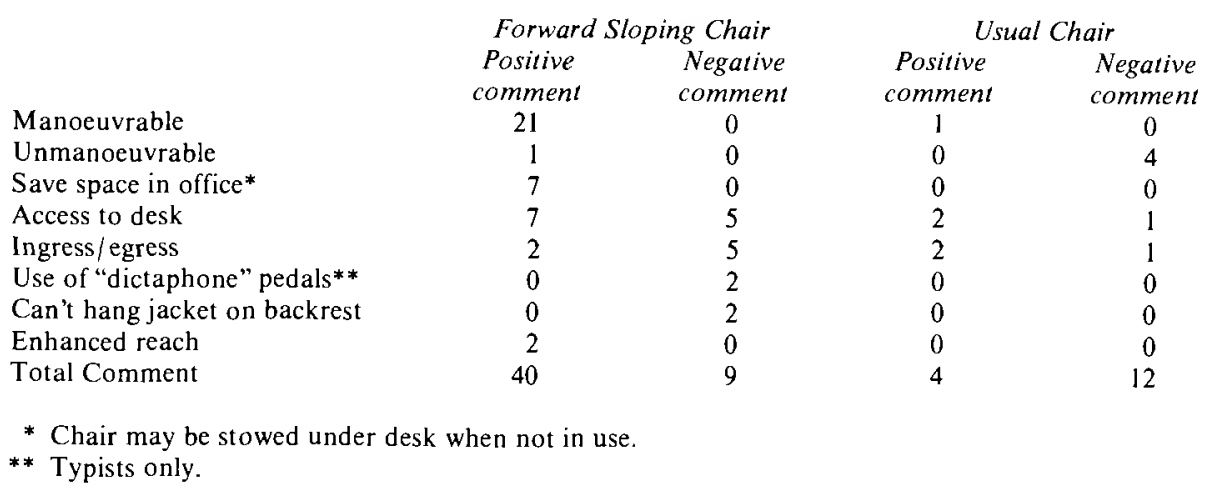

\section{Preference}

Users' preferences in office seating at the end of the trial were as follows: $63 \%$ of the sample preferred the forward sloping chair, a further $11 \%$ preferred the forward sloping chair with modification (typically, a flatter seat and/or a backrest), $8 \%$ preferred their existing chairs, $11 \%$ preferred some other type of conventional chair (typical desired features included castors and a swivelling seat where these were not present) and $7 \%$ had no preference for any chair.

\section{DISCUSSION}

Caution should be exercised in interpreting the results of this trial. Clearly, inadequacies in the existing workplaces are likely to have influenced the results. Also, it is arguable that those users who found the chair acceptable may have accepted an increase in lower limb discomfort because of the reduction in lower back pain. If this was the case, these chairs may be less acceptable to users who do not suffer from lower back pain.

However, the results of the main part of the investigation would suggest that the chair investigated merits further attention regarding its use in office settings, particularly amongst sedentary user populations in which lower back pain is prevalent.

A number of the users' comments are worthy of discussion. Generally, more comments were made about the forward sloping chair than about the conventional chairs. Participants were often indifferent or negative when discussing the latter. In view of the results of the ergonomic analysis and the novelty of the forward sloping chairs, this is not surprising.

Four participants stated that a backrest was unnecessary when using the forward sloping chair, as opposed to one participant who felt that it was necessary. Whether or not a backrest is or is not required is beyond the scope of this discussion. However, the provision of a backrest on any chair has demonstrable postural and biomechanical consequences and the relative paucity of comment on this matter is somewhat surprising.

The results of the ergonomic analysis complicate the interpretation of the back pain/discomfort data, since the observed reductions in discomfort might be attributed to improvements of an ergonomic nature due to design aspects of the forward sloping chair other than the forward sloping seat. If this were the case, it might be hypothesized that similar reductions in discomfort might be obtainable using conventional furniture which also overcome these deficiencies. This matter is open to investigation.

Some evidence for the existence of the "adjustment period" reported by Drury and Francher ${ }^{2}$ was obtained. A number of users, who eventually found the chair acceptable, initially experienced aggravation of lower back symptoms and lower limb discomfort. The duration of this period was typically one to two weeks and it only occurred in the first month of using the forward sloping chair. The present data do not enable these individuals to be distinguished from those who did not experience the adjustment period.

\section{CONCLUSIONS}

The findings of the present investigation suggest that the forward sloping chair is likely to be regarded as acceptable and comfortable by a wide range of sedentary workers. However, the data also suggest that there are factors which may contra-indicate the use of this type of chair by certain individuals. The present sample is too small to enable firm criteria to be established, although the presence of lower limb ailments would appear to be an important consideration. In this investigation, varicose veins and previous injury to the knees were associated with preference for conventional seating. Additionally, for some users, there was an adjustment period of up to two weeks, during which time the severity of symptoms increased.

Despite these observations, the main body of data indicates that chairs based on this design concept warrant the attention of those concerned with the management of chronic sedentary low back pain sufferers.

\section{Acknowledgement}

This work was supported by the Medical Research Council of South Africa and Dr Hyman Goldberg.

\section{References}

1. Bridger RS. Are you sitting comfortably? Users' perceptions of a Pelvic Tilt Chair. South African Journal of Physiotherapy 1985; 41(4): 110-115.

2. Drury $C G$ and Francher $M$. Evaluation of a Forward Sloping Chair. Applied Ergonomics 1985; 16(1): 41-47. 